\title{
FLOODING TREATMENT RESTRAINS VOLUNTEER RICE GERMINATION AND SEEDLING GROWTH
}

\author{
LUO, H. W. ${ }^{1,2 \#}-$ DU, B. ${ }^{1,2 \#}-$ ZHENG, A. X. ${ }^{1 \#}-$ LAI, R. F. ${ }^{1}-$ You, Z. S. ${ }^{1}-$ WANG, M. ${ }^{1}-$ \\ WANG, Z. M. ${ }^{3}-$ HE, L. X. ${ }^{1,2}-$ ZHANG, T. T. ${ }^{1,2}-$ TANG, X. R. ${ }^{1,2 *}$ \\ ${ }^{1}$ Department of Crop Science and Technology, College of Agriculture, South China \\ Agricultural University, Guangzhou 510642, PR China
}

${ }^{2}$ Scientific Observing and Experimental Station of Crop Cultivation in South China, Ministry of Agriculture, Guangzhou 510642, PR China

${ }^{3}$ Key Laboratory of Key Technology for South Agricultural Machine and Equipment, Ministry of Education, Guangzhou 510642, PR China

${ }^{\#}$ These authors have contributed equally to this work.

*Corresponding author

e-mail:luohaowen@stu.scau.edu.cn

(Received $7^{\text {th }}$ Aug 2018; accepted $5^{\text {th }}$ Oct 2018)

\begin{abstract}
Volunteer rice is a global problem in rice production, especially conservation tillage. Here volunteer rice from four rice cultivars viz. Xiangyaxiangzhan, Meixiangzhan, Changnongjing 1 and Yliangyoul173 was treated with different flooding treatments. Two weeks of water flooding were applied at four depths: $2.0-2.5 \mathrm{~cm}(\mathrm{~F} 1), 3.0-3.5 \mathrm{~cm}(\mathrm{~F} 2), 4.5-5 \mathrm{~cm}(\mathrm{~F} 3)$ and $6.0-6.5 \mathrm{~cm}(\mathrm{~F} 4)$. A control was set by maintaining the soil wet as normal farmer practice of this region. It was found volunteer rice germination was more reduced with increased submergence levels, while treatments F3 and F4 both decreased the germination index and germination energy greatly for all rice varieties. Flooding treatments also reduced the seedling rate and inhibited the growth of volunteer seedling. Treatments F3 and F4 decreased seedling rates of Changnongjing 1 and F2 generation of Yliangyoul 173 to zero, while the flooding treatment induced the malonaldehyde accumulation and altered the activities of peroxidase, superoxide and catalase in seedlings for all rice varieties. Hence, we suggest 2 -week flooding at soil depth $6 \mathrm{~cm}$ after the harvest of early-season rice in South China in order to prevent the harvest loss in late-season rice caused by volunteer rice.
\end{abstract}

Keywords: rice, flood, seed germination, rice seedling, anti-oxidative enzyme

\section{Introduction}

Oryza sativa L. (Rice), one of the main crops and a staple food, contributes to $35 \%-75 \%$ of caloric intake by about 3 billion people worldwide. During the rice production, the primary considerations are the yield and grain quality, which can be affected by many factors, especially volunteer rice. As a common problem in paddy field, volunteer rice emerges from the previous crop (Gealy and Gressel, 2005; Warwick et. al., 2005; Street et al., 1995) because of shattered seeds or harvest loss. The severity of this global problem in rice production differs depending mostly on the region, cultivating measures and cultivars planted. Volunteer rice in temperate regions germinates either before winter (October-November) or in spring (AprilMay) (Sudianto et al., 2013). Seeds of volunteer plants could be harvested with the cultivated rice. The grains of volunteer rice from a different variety or plant type that matures earlier or later would reduce the overall milling quality (Singh et al., 2016a). 
In tropics and subtropics, since volunteer rice germinates after the harvest, farmers take mechanical or chemical control measures to eliminate or lower the interference with the succeeding or ratooned rice. Volunteer rice is regarded as a weed phenologically and morphologically different from the planted cultivar and has lower yield and grain quality. Furthermore, volunteer rice from hybrid rice is a segregating plant that competes with crop and reduces grain yield and rice quality, thus decreasing the final productivity of paddy field and the overall level of grain quality. Thus, volunteer rice from conventional varieties is considered less influential than that from hybrid or weedy rice. Moreover, volunteer seeds from herbicide- resistant rice such as Clearfield rice ${ }^{\mathrm{TM}}$ could even become the agent for resistant gene flow between rice cultivars and natural weedy rice by outcrossing (Shivrain et al., 2007; Gressel and Valverde, 2010; Gealy et al., 2003. Normally, less than 1\% cross pollination happens between cultivars and weedy populations (Cao et al., 2006), but introgressed crop genes are able to persist in weedy population indefinitely (Ellstrand et al., 1999). Therefore, the outcrosses can promote the rise to weedy type population, which then competes with the rice cultivar and contaminates the rice, inducing economic losses.

In recent years, conservation tillage is increasingly recognized and accepted since tranditional tillage is faced by many limitations, such as poor soil structure and negative effect on soil organism. Organic farmers in Europe have great interest in conservation tillage (Peigné et al., 2018). There are many practices, including direct seeding without any tillage, or tillage at depth down to $15-20 \mathrm{~cm}$. The rice root system and soil nitrogen can accumulate in the surface soil layer in zero-tillage compared with conventional tillage (Triplett and Dick, 2008; Huang et al., 2016). During rice production in China, zero-tillage has become increasingly popular for its benefits of saving fuel, labor and equipment and conserving soil (Huang et al., 2011). However, conservation tillage is still limited by many urgent problems, including volunteer rice. In South China, rice normally grows twice each year, in March (early season) and in July (late season) (Kong et al., 2017). In conservation tillage, the volunteer rice from early season easily germinates and seedlings in late season because the paddy fields are not ploughed. As a result, the volunteer plants would compete with the rice cultivar for nutrients and sunshine. Meanwhile, because of the commensalism between volunteer plants and the rice cultivar, the rice population becomes denser and prone to inducing various diseases and insect pests, which will complicate rice management and reduce the yield and grain quality of late season rice.

As reported, winter-flood reduced the germination rate of volunteer rice (Singh et al., 2016a), indicating flood treatment could be an effective means to deal with volunteer rice in double-cropping rice in South China. Under the hypothesis that flood treatment can reduce the germination of volunteer rice and the growth of volunteer seedlings, we conducted experiments in artificial weather boxes.

\section{Materials and methods}

\section{Seed materials}

Seeds from two fragrant rice cultivars (Meixiangzhan, Xiangyaxiangzhan), one japonica rice cultivar (Changnongjing 1, Yangtze University, Hubei, China) and the F2 generation of hybrid rice (Yliangyoul173) were used as the experimental 
materials (Those cultivars were well-known and widely grown in South China). Seeds of early season rice were collected from College of Agriculture, South China Agricultural University, Guangzhou, China. All seeds were obtained from the upper parts of panicle.

\section{Flood treatment and growth conditions}

Normally, there was about two weeks between the harvest of early season and transplantation of late season rice in South China. Hence, after sowing seeds into soil-containing plastic pots $\left(100 \times 80 \times 20 \mathrm{~cm}^{3} ; 500\right.$ seeds in each pot $)$, we began the 2-week flood treatments as follows:

CK: soil was contained wet without any water layer at soil surface.

F1, F2, F3, F4: 2.0-2.5, 3-3.5, 4.5-5, 6-6.5 cm water layer were maintained at soil surface, respectively.

After the treatments F1, F2, F3 and F4, the water layers were drained off and all the pots contained wet soil without any water layer for a week in order to determinate the seedling rate and some biochemical indicators. The temperature for germination and growth was $33{ }^{\circ} \mathrm{C}$ in the day and $27{ }^{\circ} \mathrm{C}$ at night under $1200 \mathrm{X}$ yellow light. The experimental soil was sandy loam containing $1.443 \%$ total nitrogen, $24.56 \%$ organic matter, $0.927 \%$ total phosphorous and $18.220 \%$ total potassium at $\mathrm{pH} 6.54$.

\section{Seed bioassay}

After sowing, the germination of each treatment was observed daily for 7 days according to the Association of Official Seed Analysis (Wiesner, 1990). The number of days to reach $50 \%$ germination $\left(\mathrm{T}_{50}\right)$ was calculated by a devised method with modification (Farooq et al., 2013):

$$
T 50=t i+\frac{\left(\frac{N}{2}-n i\right)(t j-t i)}{n j-n i}
$$

where $N$ is the final number of emerged seeds; $n_{\mathrm{i}}$ and $n_{\mathrm{j}}$ are the cumulative numbers of emerged seeds at time $t_{\mathrm{i}}$ and $t_{\mathrm{j}}$ respectively when $n_{\mathrm{i}}<N / 2<n_{\mathrm{j}}$.

Mean germination time (MGT) was calculated as follows (Ellis, 1981):

$$
\mathrm{MGT}=\Sigma \mathrm{Dn} / \Sigma \mathrm{n}
$$

where $n$ is the number of emerged seeds on day $D$, which is counted from the beginning of emergence.

Germination index (GI) was calculated according to the equation of Association of Official Seed Analysis:

$$
\mathrm{GI}=\frac{\text { No. of emerged seeds }}{\text { Days of first count }}+\ldots \ldots+\frac{\text { No. of emerged seeds }}{\text { Days of final count }}
$$


The energy of germination $(G E)$ was observed on the 3rd day after sowing. This percentage of germinating seeds $3 \mathrm{~d}$ after sowing is relative to the total number of seeds tested (Ruan et al., 2002).

The radicle and plumule lengths of twenty seedlings randomly selected from each experimental unit were measured $7 \mathrm{~d}$ after sowing. Three weeks after sowing, seedling rate was recorded while 30 seedlings randomly selected from each experimental unit were measured for fresh weight and then oven-dried at $80{ }^{\circ} \mathrm{C}$ for $48 \mathrm{~h}$ to determine the dry biomass.

\section{Biochemical analyses}

After malonaldehyde (MDA) reacted with thiobarbital acid, absorbance of solutions was recorded at 532, 600, and $450 \mathrm{~nm}$. The MDA content ( $\mu \mathrm{mol} / \mathrm{L})$ was determined as $=6.45($ OD532 - OD600) $-0.560 D 450$ (Pan, 2013), and final result was expressed as $\mu \mathrm{mol} / \mathrm{g} \mathrm{FW}$.

The superoxide (SOD, EC 1.15.1.1) activity was detected according to Zhang (Zhang et al., 2008). The reaction mixture contained $1.75 \mathrm{ml}$ of sodium phosphate buffer (SPB, pH 7.8), $0.3 \mathrm{ml}$ of $130 \mathrm{mM} \cdot 1^{-1}$ methionine buffer, $0.3 \mathrm{ml}$ of 750 $\mu \mathrm{mol} \cdot 1^{-1}$ nitroblue tetrazolium (NBT) buffer, $0.3 \mathrm{ml}$ of $100 \mu \mathrm{mol} \cdot 1^{-1}$ ethylene diamine tetraacetic acid disodium (EDTA-Na $\mathrm{N}_{2}$ ) buffer, $0.3 \mathrm{ml}$ of $20 \mu \mathrm{mol} \cdot 1^{-1}$ lactoflavin and $0.05 \mathrm{ml}$ of enzyme extract. The color change was measured at $560 \mathrm{~nm}$ after the reaction. One unit of activity was equal to the volume of extract needed to inhibit $50 \%$ of the color reaction. The peroxidase (POD EC1.11.1.7) activity was examined according to $\mathrm{Yu}$ (Xia et al., 2009). Enzyme extract $(50 \mu \mathrm{l})$ was added to the reaction solution which contained $1 \mathrm{ml}$ of $0.3 \% \mathrm{H}_{2} \mathrm{O}_{2}, 0.95 \mathrm{ml}$ of $0.2 \%$ guaiacol, and $1 \mathrm{ml}$ of $50 \mathrm{mM} \cdot 1^{-1}$ SPB (pH 7.0). The absorbance was read at $470 \mathrm{~nm}$. One unit of POD activity was expressed as the absorbance increase because of guaiacol oxidation by 0.01 (U/g FW). Catalase (CAT, EC 1.11.1.6) activity was measured according to Aebi (1984). An aliquot of enzyme extract $(50 \mu \mathrm{l})$ was added to the reaction solution containing $1 \mathrm{ml}$ of $0.3 \% \mathrm{H}_{2} \mathrm{O}_{2}$ and $1.95 \mathrm{ml}$ of SPB and, the absorbance was recorded at $240 \mathrm{~nm}$. One unit of CAT activity was expressed as the absorbance decrease by $0.01(\mathrm{U} / \mathrm{g} \mathrm{FW})$.

\section{Statistical analyses}

Data were analyzed using Statistix 8.1 (Analytical Software, Tallahassee, FL, USA) while differences among means were separated by using least significant difference (LSD) test at the 5\% probability level. Graphical representation was conducted via Sigma Plot 14.0 (Systat Software Inc., California, USA).

\section{Results}

\section{Germination rate}

Flooding treatment significantly affected the emergence of volunteer rice. The germination of seeds started after 3 days in both treatments F3 and F4 for all rice varieties (Fig. 1). For Xiangyaxiangzhan, the speeds of germination were not significantly different among treatments $\mathrm{CK}, \mathrm{F} 1$ and F2, but were significantly slowed down after treatments F3 and F4. Similar trend was found in Meixiangzhan. 
For both Changnongjing 1 and F2 generation of Yliangyoul173, the trend of speed germination was recorded as: $\mathrm{CK}>\mathrm{F} 1>\mathrm{F} 2>\mathrm{F} 3>\mathrm{F} 4$.

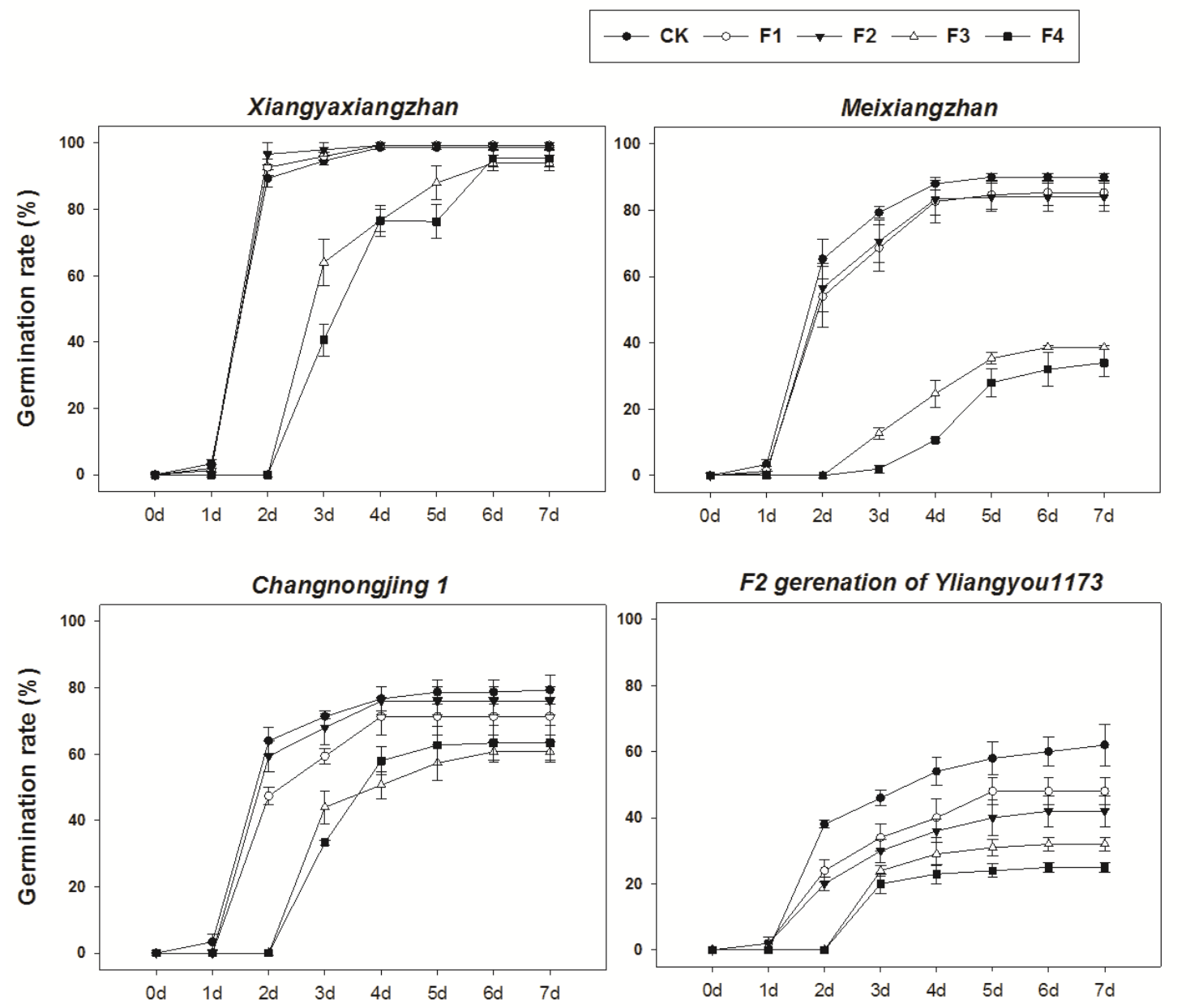

Figure 1. Effects of flood treatments on germination rate of volunteer rice

\section{Emergence attributes}

Flooding treatments influenced germination vigor significantly (Table 1). Treatments F3 and F4 both decreased the GI, GE, lengths of radicle and plumule, but increased the MGT and $\mathrm{T}_{50}$ significantly for all rice varieties. For Xiangyaxiangzhan, GIs in F3 and F4 declined by $43.56 \%$ and $47.72 \%$, respectively, and GEs in F3 and F4 decreased by $22.29 \%$ and $22.37 \%$, respectively, compared with CK. For Meixiangzhan, the lowest GI, GE and FGP were found in F4; Compared with CK, GIs in F3 and F4 decreased by $77.42 \%$ and $85.32 \%$, respectively, while $71.97 \%$ and $87.88 \%$ lower were recorded in F3 and F4, respectively. For Changnongjing 1, no significant difference between treatments F3 and F4 was found in GI, GE or FGP, while GI, GE and FGP significantly all declined in F3 and F4. For F2 generation of Yliangyou1173, the changing trend of GI, GE and FGP was recorded as: CK > F1 > F2 > F3 > F4, while F3 and F4 prolonged MGT and T50 significantly. Furthermore, F1 and F2 treatments did not significantly affect FGP for Xiangyaxiangzhan, Meixiangzhan or Changnongjing 1 whilst both F3 and F4 decreased the lengths of radicle and plumule for all 4 varieties compared with CK. 
Table 1. Effects of flooding treatments on the germination vigor of volunteer rice

\begin{tabular}{|c|c|c|c|c|c|c|c|c|}
\hline \multicolumn{2}{|l|}{ Treatments } & $\begin{array}{l}\text { MGT } \\
\text { (d) }\end{array}$ & $\begin{array}{l}T_{50} \\
(d)\end{array}$ & GI & $\begin{array}{r}\text { GE } \\
(\%)\end{array}$ & $\begin{array}{l}\text { FGP } \\
(\%)\end{array}$ & $\begin{array}{l}\text { Radicle } \\
\text { length } \\
(\mathbf{c m})\end{array}$ & $\begin{array}{c}\text { Plumule } \\
\text { length } \\
\text { (cm) }\end{array}$ \\
\hline \multirow{5}{*}{ Xiangyaxiangzhan } & CK & $4.53 \pm 0.02 \mathrm{c}$ & $1.50 \pm 0.03 \mathrm{c}$ & $77.25 \pm 1.57 \mathrm{a}$ & $98.67 \pm 0.67 \mathrm{a}$ & $98.67 \pm 0.67 \mathrm{ab}$ & $5.35 \pm 1.06 \mathrm{bc}$ & $4.27 \pm 0.16 \mathrm{~b}$ \\
\hline & F1 & $4.53 \pm 0.02 \mathrm{c}$ & $1.52 \pm 0.03 \mathrm{c}$ & $77.56 \pm 0.96 \mathrm{a}$ & $99.33 \pm 0.67 \mathrm{a}$ & $99.33 \pm 0.67 \mathrm{a}$ & $7.68 \pm 0.59 \mathrm{a}$ & $5.72 \pm 0.71 \mathrm{a}$ \\
\hline & $\mathrm{F} 2$ & $4.50 \pm 0.02 \mathrm{c}$ & $1.48 \pm 0.02 \mathrm{c}$ & $79.22 \pm 0.96 \mathrm{a}$ & $99.33 \pm 0.67 \mathrm{a}$ & $99.33 \pm 0.67 \mathrm{a}$ & $5.98 \pm 0.25 b$ & $5.32 \pm 0.42 \mathrm{a}$ \\
\hline & F3 & $5.19 \pm 0.05 b$ & $2.75 \pm 0.07 b$ & $43.60 \pm 2.23 b$ & $76.67 \pm 4.67 b$ & $94.00 \pm 2.31 b$ & $4.37 \pm 0.64 \mathrm{~cd}$ & $3.09 \pm 0.44 \mathrm{c}$ \\
\hline & $\mathrm{F} 4$ & $5.32 \pm 0.02 \mathrm{a}$ & $3.28 \pm 0.04 \mathrm{a}$ & $40.38 \pm 1.74 \mathrm{~b}$ & $76.59 \pm 3.33 b$ & $95.33 \pm 2.40 \mathrm{ab}$ & $3.58 \pm 0.41 \mathrm{~d}$ & $3.70 \pm 0.49 \mathrm{bc}$ \\
\hline \multirow{5}{*}{ Meixiangzhan } & CK & $4.63 \pm 0.04 c$ & $1.63 \pm 0.08 \mathrm{c}$ & $65.15 \pm 2.83 \mathrm{a}$ & $88.00 \pm 2.00 \mathrm{a}$ & $90.00 \pm 1.15 \mathrm{a}$ & $6.12 \pm 1.06 \mathrm{a}$ & $4.68 \pm 0.40 \mathrm{a}$ \\
\hline & $\mathrm{F} 1$ & $4.72 \pm 0.08 \mathrm{c}$ & $1.80 \pm 0.13 \mathrm{c}$ & $57.62 \pm 5.34 \mathrm{a}$ & $82.67 \pm 6.36 \mathrm{a}$ & $85.33 \pm 3.71 \mathrm{a}$ & $2.92 \pm 0.35 \mathrm{~b}$ & $3.20 \pm 0.73 b c$ \\
\hline & $\mathrm{F} 2$ & $4.69 \pm 0.04 \mathrm{c}$ & $1.75 \pm 0.08 \mathrm{c}$ & $58.09 \pm 4.73 \mathrm{a}$ & $83.33 \pm 4.81 \mathrm{a}$ & $84.00 \pm 4.16 \mathrm{a}$ & $4.42 \pm 0.71 \mathrm{~b}$ & $4.30 \pm 0.49 \mathrm{ab}$ \\
\hline & F3 & $5.45 \pm 0.08 b$ & $3.63 \pm 0.27$ & $14.71 \pm 0.83 b$ & $24.67 \pm 4.06 \mathrm{~b}$ & $38.67 \pm 0.67 \mathrm{~b}$ & $4.38 \pm 0.43 b$ & $2.41 \pm 0.44 \mathrm{c}$ \\
\hline & $\mathrm{F} 4$ & $5.80 \pm 0.04 \mathrm{a}$ & $4.38 \pm 0.03$ & $9.56 \pm 1.24 \mathrm{~b}$ & $10.67 \pm 0.67 \mathrm{c}$ & $34.00 \pm 4.00 \mathrm{~b}$ & $4.51 \pm 0.92 \mathrm{ab}$ & $3.22 \pm 0.74 b c$ \\
\hline \multirow{5}{*}{ Changnongjing 1} & CK & $4.58 \pm 0.04 \mathrm{c}$ & $1.55 \pm 0.02 \mathrm{~d}$ & $59.23 \pm 1.50 \mathrm{a}$ & $76.67 \pm 3.71 \mathrm{a}$ & $79.33 \pm 4.37 \mathrm{a}$ & $7.48 \pm 0.73 \mathrm{a}$ & $3.72 \pm 0.18 \mathrm{a}$ \\
\hline & $\mathrm{F} 1$ & $4.69 \pm 0.06 \mathrm{~b}$ & $1.76 \pm 0.09 \mathrm{c}$ & $48.81 \pm 2.36 \mathrm{~b}$ & $71.33 \pm 5.70 \mathrm{a}$ & $71.33 \pm 5.70 \mathrm{abc}$ & $5.80 \pm 0.56 \mathrm{~b}$ & $2.22 \pm 0.13 b$ \\
\hline & $\mathrm{F} 2$ & $4.63 \pm 0.02 b c$ & $1.64 \pm 0.02 \mathrm{~cd}$ & $55.03 \pm 3.56 \mathrm{ab}$ & $76.00 \pm 4.16 \mathrm{a}$ & $76.00 \pm 4.16 \mathrm{ab}$ & $5.50 \pm 1.03 \mathrm{~b}$ & $2.28 \pm 0.32 b$ \\
\hline & F3 & $5.16 \pm 0.03 \mathrm{a}$ & $2.70 \pm 0.05 \mathrm{~b}$ & $28.79 \pm 2.31 \mathrm{c}$ & $50.67 \pm 4.06 \mathrm{~b}$ & $60.67 \pm 2.96 \mathrm{c}$ & $2.37 \pm 0.21 \mathrm{c}$ & $1.68 \pm 0.33 \mathrm{c}$ \\
\hline & $\mathrm{F} 4$ & $5.23 \pm 0.02 \mathrm{a}$ & $2.95 \pm 0.06 \mathrm{a}$ & $28.87 \pm 2.01 \mathrm{c}$ & $58.00 \pm 4.16 \mathrm{~b}$ & $63.33 \pm 5.21 \mathrm{bc}$ & $2.12 \pm 0.04 \mathrm{c}$ & $1.05 \pm 0.17 \mathrm{~d}$ \\
\hline \multirow{5}{*}{$\begin{array}{c}\text { F2 generation of } \\
\text { Yliangyou } 1173\end{array}$} & $\mathrm{CK}$ & $4.76 \pm 0.03 b$ & $1.81 \pm 0.06 \mathrm{c}$ & $39.15 \pm 2.48 \mathrm{a}$ & $3.20 \pm 0.40 \mathrm{ab}$ & $62.00 \pm 6.24 \mathrm{a}$ & $4.33 \pm 0.85 \mathrm{a}$ & $3.20 \pm 0.40 \mathrm{ab}$ \\
\hline & $\mathrm{F} 1$ & $4.83 \pm 0.06 \mathrm{~b}$ & $2.14 \pm 0.12 b$ & $29.90 \pm 3.54 b$ & $3.98 \pm 0.46 \mathrm{a}$ & $48.00 \pm 4.04 \mathrm{~b}$ & $4.32 \pm 0.75 \mathrm{a}$ & $3.98 \pm 0.46 \mathrm{a}$ \\
\hline & $\mathrm{F} 2$ & $4.81 \pm 0.06 \mathrm{~b}$ & $2.08 \pm 0.10 \mathrm{bc}$ & $26.00 \pm 1.92 \mathrm{~b}$ & $3.03 \pm 0.61 \mathrm{~b}$ & $42.00 \pm 4.62 \mathrm{bc}$ & $3.33 \pm 0.77 \mathrm{ab}$ & $3.03 \pm 0.61 \mathrm{~b}$ \\
\hline & F3 & $5.13 \pm 0.02 \mathrm{a}$ & $2.67 \pm 0.02 \mathrm{a}$ & $15.68 \pm 1.25 \mathrm{c}$ & $3.15 \pm 0.33 \mathrm{ab}$ & $32.00 \pm 2.08 \mathrm{~cd}$ & $3.10 \pm 0.29 \mathrm{ab}$ & $3.15 \pm 0.33 \mathrm{ab}$ \\
\hline & $\mathrm{F} 4$ & $5.11 \pm 0.06 \mathrm{a}$ & $2.65 \pm 0.08 \mathrm{a}$ & $12.48 \pm 1.24 \mathrm{c}$ & $2.73 \pm 0.15 b$ & $25.00 \pm 1.53 \mathrm{~d}$ & $2.40 \pm 0.21 \mathrm{~b}$ & $2.73 \pm 0.15 b$ \\
\hline
\end{tabular}

Figures not sharing the same letters differ significantly at $\mathrm{P}=0.05$ (the same below). FGP: final germination percentage

\section{Seedling quality}

Flooding treatments reduced the seedling quality of volunteer rice significantly. The trend of seedling rate was recorded as: $\mathrm{CK}>\mathrm{F} 1>\mathrm{F} 2>\mathrm{F} 3>\mathrm{F} 4$ for both Xiangyaxiangzhan and Meixiangzhan (Table 2). In treatments F1 and F2 compared with CK, seedling rate was $81.51 \%$ and $81.94 \%$ lower in Changnongjing 1 , respectively, while 43.55 and 57.98 lower in F2 generation of Yliangyou 1173, respectively. No seed could grow or develop into a whole seedling in F3 or F4 for either Changnongjing 1 or F2 generation of Yliangyou1173. Moreover, dry weights were 5.2\%, 10.09\%, 45.15\% and $39.58 \%$ lower in F1, F2, F3 and F4 respectively for Xiangyaxiangzhan, respectively. For Meixiangzhan, the trend of dry weight was recorded as: CK > F1 > F2 $>\mathrm{F} 3>\mathrm{F} 4$. Both F1 and F2 decreased the dry weight in Changnongjing 1 and F2 generation of Yliangyoul173.

\section{MDA contents and anti-oxidant responses of seedlings}

Flooding treatments influenced the anti-oxidative activities in terms of POD, SOD and CAT, and caused oxidative damage by increasing lipid per-oxidation (MDA content). For Xiangxiangzhan, MDA contents in F1, F2, F3 and F4 were 19.39\%, $10.20 \%, 36.73 \%$ and $64.29 \%$ higher, respectively. POD and CAT activities in F1 and F2 all were higher than CK while lower in F3 and F4. Similar discussion was found in Meixiangzhan. For Meixiangzhan, MDA contents were 12.33, 11.53, 37.09 and $85.11 \%$ higher in F1, F2, F3 and F4, respectively. Highest and lowest SOD activity were recorded in $\mathrm{F} 2$ and $\mathrm{F} 4$, respectively. For Changnongjing 1 and F2 generation of Yliangyou1173, both F1 and F2 treatments reduced the activities of POD, SOD and CAT while promoting the production of MDA (Table 3). 
Table 2. Effect of flood treatments on seedling quality of volunteer rice

\begin{tabular}{|c|c|c|c|c|}
\hline \multicolumn{2}{|l|}{ Treatments } & Seedling rate $(\%)$ & Fresh weight (mg) & Dry weight (mg) \\
\hline \multirow{5}{*}{ Xiangyaxiangzhan } & $\mathrm{CK}$ & $98.67 \pm 0.67 \mathrm{a}$ & $63.43 \pm 1.26 \mathrm{a}$ & $9.22 \pm 0.21 \mathrm{a}$ \\
\hline & $\mathrm{F} 1$ & $88.67 \pm 1.77 b$ & $57.87 \pm 1.41 \mathrm{ab}$ & $8.75 \pm 0.13 \mathrm{a}$ \\
\hline & $\mathrm{F} 2$ & $65.67 \pm 3.48 \mathrm{c}$ & $64.50 \pm 0.79 \mathrm{a}$ & $8.29 \pm 0.29 \mathrm{a}$ \\
\hline & F3 & $64.33 \pm 3.48 \mathrm{c}$ & $45.80 \pm 1.01 \mathrm{c}$ & $5.06 \pm 0.35 b$ \\
\hline & $\mathrm{F} 4$ & $48.67 \pm 3.71 \mathrm{~d}$ & $53.28 \pm 4.89 \mathrm{bc}$ & $5.57 \pm 0.90 \mathrm{~b}$ \\
\hline \multirow{5}{*}{ Meixiangzhan } & $\mathrm{CK}$ & $90.00 \pm 1.15 \mathrm{a}$ & $97.92 \pm 1.81 \mathrm{a}$ & $15.62 \pm 0.61 \mathrm{a}$ \\
\hline & $\mathrm{F} 1$ & $74.00 \pm 6.11 \mathrm{~b}$ & $83.81 \pm 2.34 \mathrm{ab}$ & $11.37 \pm 0.28 b$ \\
\hline & F2 & $68.00 \pm 4.00 \mathrm{~b}$ & $78.55 \pm 3.96 b$ & $10.30 \pm 0.12 b$ \\
\hline & F3 & $26.00 \pm 1.56 \mathrm{c}$ & $66.88 \pm 5.21 b$ & $7.81 \pm 0.58 \mathrm{c}$ \\
\hline & $\mathrm{F} 4$ & $18.67 \pm 2.52 \mathrm{c}$ & $72.12 \pm 10.69 b$ & $6.86 \pm 0.54 \mathrm{c}$ \\
\hline \multirow{5}{*}{ Changnongjing 1} & $\mathrm{CK}$ & $79.33 \pm 4.37 \mathrm{a}$ & $105.62 \pm 2.13 \mathrm{a}$ & $14.58 \pm 1.34 \mathrm{a}$ \\
\hline & $\mathrm{F} 1$ & $14.67 \pm 0.67 b$ & $62.29 \pm 1.72 b$ & $8.48 \pm 0.38 b$ \\
\hline & $\mathrm{F} 2$ & $14.33 \pm 2.33 b$ & $57.45 \pm 2.01 \mathrm{c}$ & $7.86 \pm 0.12 b$ \\
\hline & F3 & 0 & - & - \\
\hline & $\mathrm{F} 4$ & 0 & - & - \\
\hline \multirow{5}{*}{ F2 generation of Yliangyoul173 } & CK & $62.00 \pm 6.24 \mathrm{a}$ & $85.24 \pm 1.88 \mathrm{a}$ & $8.80 \pm 0.31 \mathrm{a}$ \\
\hline & $\mathrm{F} 1$ & $35.00 \pm 2.65 b$ & $32.31 \pm 1.45 b$ & $3.48 \pm 0.28 b$ \\
\hline & $\mathrm{F} 2$ & $26.05 \pm 2.10 \mathrm{~b}$ & $34.19 \pm 1.10 \mathrm{~b}$ & $3.35 \pm 0.24 b$ \\
\hline & $\mathrm{F} 3$ & 0 & - & - \\
\hline & F4 & 0 & - & - \\
\hline
\end{tabular}

Table 3. Effects of flood treatments on MDA contents and anti-oxidant responses of seedlings

\begin{tabular}{|c|c|c|c|c|c|}
\hline \multicolumn{2}{|l|}{ Treatments } & $\begin{array}{c}\text { POD } \\
\left(\mathbf{U} \cdot \mathbf{g}^{-1} \cdot \mathbf{m i n}^{-1)}\right.\end{array}$ & $\begin{array}{l}\text { SOD } \\
(\mathbf{U} \cdot \mathbf{g}-1)\end{array}$ & $\begin{array}{c}\text { CAT } \\
(\mathrm{U} \cdot \mathrm{g}-1 \cdot \mathrm{min}-1)\end{array}$ & $\begin{array}{c}\text { MDA } \\
\text { (umol'g-1) }\end{array}$ \\
\hline \multirow{5}{*}{ Xiangyaxiangzhan } & $\mathrm{CK}$ & $124.33 \pm 2.60 \mathrm{c}$ & $178.67 \pm 2.91 \mathrm{~b}$ & $160.59 \pm 2.91 \mathrm{c}$ & $3.27 \pm 0.12 \mathrm{c}$ \\
\hline & F1 & $133.67 \pm 0.89 \mathrm{~b}$ & $185.67 \pm 2.02 \mathrm{ab}$ & $169.25 \pm 1.54 \mathrm{~b}$ & $3.90 \pm 0.17 b c$ \\
\hline & F2 & $145.02 \pm 4.04 \mathrm{a}$ & $193.33 \pm 2.34 \mathrm{a}$ & $179.32 \pm 3.13 \mathrm{a}$ & $3.60 \pm 0.06 \mathrm{c}$ \\
\hline & F3 & $105.33 \pm 2.73 \mathrm{~d}$ & $164.79 \pm 3.18 \mathrm{c}$ & $143.10 \pm 2.39 \mathrm{~d}$ & $4.47 \pm 0.26 \mathrm{~b}$ \\
\hline & $\mathrm{F} 4$ & $89.33 \pm 1.45 \mathrm{e}$ & $147.15 \pm 4.09 \mathrm{~d}$ & $125.61 \pm 1.70 \mathrm{e}$ & $5.38 \pm 0.24 \mathrm{a}$ \\
\hline \multirow{5}{*}{ Meixiangzhan } & CK & $113.33 \pm 2.71 \mathrm{c}$ & $201.74 \pm 4.09 b$ & $153.59 \pm 3.80 \mathrm{c}$ & $3.76 \pm 0.14 \mathrm{c}$ \\
\hline & $\mathrm{F} 1$ & $122.09 \pm 1.08 \mathrm{~b}$ & $213.81 \pm 3.78 \mathrm{a}$ & $162.25 \pm 1.64 \mathrm{~b}$ & $4.22 \pm 0.20 b c$ \\
\hline & $\mathrm{F} 2$ & $134.15 \pm 3.06 \mathrm{a}$ & $216.51 \pm 2.81 \mathrm{a}$ & $172.32 \pm 4.37 \mathrm{a}$ & $4.19 \pm 0.13 b c$ \\
\hline & F3 & $94.33 \pm 2.13 \mathrm{~d}$ & $187.17 \pm 2.17 \mathrm{c}$ & $136.10 \pm 2.80 \mathrm{~d}$ & $5.15 \pm 0.30 \mathrm{~b}$ \\
\hline & $\mathrm{F} 4$ & $78.33 \pm 0.96 \mathrm{e}$ & $174.00 \pm 1.53 \mathrm{~d}$ & $118.61 \pm 2.86 \mathrm{e}$ & $6.96 \pm 0.28 \mathrm{a}$ \\
\hline \multirow{5}{*}{ Changnongjingone } & CK & $154.33 \pm 2.19 \mathrm{a}$ & $238.46 \pm 3.11 \mathrm{a}$ & $190.59 \pm 4.05 \mathrm{a}$ & $2.11 \pm 0.03 \mathrm{c}$ \\
\hline & $\mathrm{F} 1$ & $131.25 \pm 1.45 b$ & $164.12 \pm 5.17 \mathrm{~b}$ & $137.00 \pm 4.16 \mathrm{~b}$ & $6.40 \pm 0.29 b$ \\
\hline & $\mathrm{F} 2$ & $104.67 \pm 1.86 \mathrm{c}$ & $128.00 \pm 5.19 \mathrm{c}$ & $118.76 \pm 4.36 c$ & $7.77 \pm 0.19 a$ \\
\hline & F3 & - & - & - & - \\
\hline & $\mathrm{F} 4$ & - & - & - & - \\
\hline \multirow{5}{*}{$\begin{array}{c}\text { F2 generation of } \\
\text { Yliangyoul173 }\end{array}$} & CK & $107.67 \pm 1.91 \mathrm{a}$ & $143.00 \pm 2.08 \mathrm{a}$ & $132.85 \pm 2.08 \mathrm{a}$ & $5.13 \pm 0.15 c$ \\
\hline & $\mathrm{F} 1$ & $84.33 \pm 2.91 \mathrm{~b}$ & $115.84 \pm 2.09 \mathrm{~b}$ & $106.00 \pm 1.33 b$ & $8.45 \pm 0.19 b$ \\
\hline & $\mathrm{F} 2$ & $67.61 \pm 1.79 \mathrm{c}$ & $97.55 \pm 4.10 \mathrm{c}$ & $87.63 \pm 3.14 c$ & $10.08 \pm 0.38 \mathrm{a}$ \\
\hline & F3 & - & - & - & - \\
\hline & F4 & - & - & - & - \\
\hline
\end{tabular}




\section{Correlation analysis}

Seedling rate was significantly and positively correlated with dry weight, POD, SOD, CAT, GI, GE, and FGP (Table 4). Significant positive correlations were also observed among GI, GE and FGP, but negative correlations were found between MDA and seedling rate and between $\mathrm{T}_{50}$ and FGP.

Table 4. Relationship between seedling rate, anti-oxidant responses and seed bioassay

\begin{tabular}{|c|c|c|c|c|c|c|c|c|c|c|}
\hline Index & $\begin{array}{l}\text { Seedling } \\
\text { rate }\end{array}$ & $\begin{array}{c}\text { Dry } \\
\text { weight }\end{array}$ & POD & SOD & CAT & MDA & GI & GE & $\mathbf{T}_{50}$ & FGP \\
\hline $\begin{array}{c}\text { Dry } \\
\text { weight }\end{array}$ & $0.600^{*}$ & & & & & & & & & \\
\hline POD & $0.585^{*}$ & $0.679 * *$ & & & & & & & & \\
\hline SOD & $0.585^{*}$ & $0.805 * *$ & $0.749 * *$ & & & & & & & \\
\hline CAT & $0.742 * *$ & $0.731 * *$ & $0.919 * *$ & $0.904 * *$ & & & & & & \\
\hline MDA & $-0.778 * *$ & $-0.715^{* *}$ & $-0.754 * *$ & $-0.878 * *$ & $-0.920 * *$ & & & & & \\
\hline GI & $0.759 * *$ & $0.526^{*}$ & $0.797 * *$ & 0.452 & $0.735 * *$ & $-0.597 *$ & & & & \\
\hline GE & $0.735 * *$ & 0.466 & $0.749 * *$ & 0.423 & $0.699 * *$ & $-0.605^{*}$ & $0.962 * *$ & & & \\
\hline $\mathrm{T}_{50}$ & $-0.522 *$ & -0.424 & $-0.650 * *$ & -0.155 & -0.449 & 0.212 & $-0.807 * *$ & $-0.732 * *$ & & \\
\hline FGP & $0.739 * *$ & 0.394 & $0.666 * *$ & 0.424 & $0.676^{* *}$ & $-0.659 * *$ & $0.884 * *$ & $0.967 * *$ & $-0.554 *$ & \\
\hline $\begin{array}{l}\text { Plumule } \\
\text { length }\end{array}$ & $0.716 * *$ & 0.263 & 0.413 & 0.357 & $0.543 *$ & -0.482 & $0.644 * *$ & $0.560 *$ & -0.382 & $0.555^{*}$ \\
\hline
\end{tabular}

Significant correlations as $* \mathrm{P}<0.05$ and $* * \mathrm{P}<0.01$

\section{Discussion}

Volunteer rice is a global problem of rice production, especially in conservation tillage. In the United States, areas of rice growing normally begin to be flooded from early autumn after the rice harvest until the tillage operations in spring (Fogliatto et al., 2010) because anaerobic environment could limit the germination and growth of abundant weeds such as weedy rice (Bird et al., 2002). The present study confirms this view by showing the decline of emergence properties of volunteer rice in flooding treatments. Specifically, the germination speed slowed as the water layer increased, especially F3 and F4. Once the water layer was over $4.5 \mathrm{~cm}$, the time to start germination was extended and the quantity of eventually germinated volunteer rice was weakened. Flooding treatment significantly altered the germination characteristics of volunteer rice. Since the seed germination and seedling establishment phase is highly vulnerable to injury, disease and stress, we believe this phase is a key time period to prevent harvest loss caused by volunteer rice. Germination vigor is driven by the ability of plant embryos, embedded in seeds, to resume the metabolic activity in a coordinated and sequential manner (Rajjou et al., 2012). The germination vigor can be evaluated using many indexes. We observed that as water layer rose in flooding treatments, MGT and $\mathrm{T}_{50}$ were prolonged for most rice varieties while the GI and GE reduced. Both F4 and F3 significantly influenced volunteer rice germination by minimizing the germination rate, and drastically declined both radicle and plumule lengths for all rice varieties. These results agreed with Prakash (Rajjou et al., 2012) who found rice germination was further reduced with the rise of submergence levels. In addition, the volunteer rice from Xiangyaxiangzhan was strongly tolerant against submergence. The FGPs in F1, F2, F3 and F4 were all not significantly different from those in CK. Thus, 
Xiangyaxiangzhan might be one of the tolerant genotypes against flooding stress. The flooding tolerance during germination is a complicated process involving many mechanisms. Ismail already identified several genotypes with higher flooding tolerance during germination (Ismail et al., 2009). However, the submergence tolerance during germination is associated with the flooding tolerance during the vegetative stage, as reported in the sensitivity of FR13A, a landrace that is most tolerant of complete inundation during this stage (Ella et al., 2003; Jackson and Ram, 2003).

We also noticed flooding treatment greatly reduced seedling rate and dry matter weight. As reported similarly, flooding treatments decreased root, shoot and total dry matter production in all rice cultivars and with more reduction in higher than lower flooding levels (5 vs. $1 \mathrm{~cm}$ ) (Prakash et al., 2016a). These results indicate the seeds of volunteer rice even under the flooding environment could germinate successfully, but the chance of developing into whole normal seedlings was very low, which was greatly embodied by the zero seedling rates of both Changnongjing 1 and F2 generation of Yliangyoul173 in treatments F3 and F4. After 3 weeks of treatment, MDA production in volunteer seedlings was enhanced with the increasing submergence level. The MDA over-accumulation might be attributed to oxidation of polyunsaturated fatty acids (e.g., lineolenic acids, galacto- and phosphp-lipid components), which are critical in the functional and structural characteristics of thylakoid membranes and the arrangement of reaction centers of photosystems (Elshintinawy, 2000). MDA also reacts with free amino acids to even form ethylene in cellular membranes (Rakwal et al., 2003; Jiang and Zhang, 2002). Thus, MDA accumulation is a key indicator of oxidative stress, which is characteristic of intercellular and intracellular membranes and hence intensifies the ion leakage through cell membranes (Dash and Mohanty, 2002). In this study, the improvement of MDA content meant flooding treatment caused submergence stress and some oxidative damage to volunteer seedlings. Furthermore, the anti-oxidative enzymatic activities all differed maong the flooding conditions. Anti-oxidant plays an important role in quenching reactive oxygen species. For example, when superoxide radicals accumulate in organisms, SOD is responsible for breakdown and then POD and CAT are involved in scavenging $\mathrm{H}_{2} \mathrm{O}_{2}$ (Sairam et al., 2000). In the present study, treatments F1 and F2 both enhanced the activities of POD, SOD and CAT for both Xiangyaxiangzhan and Meixiangzhan, whilst F3 and F4 greatly decreased the antioxidative enzymatic activities. The main reason might be that lower flooding level (1.5$3.5 \mathrm{~cm}$ ) already caused oxidative stress to rice seedlings, but the damage could be mitigated by the anti-oxidant regulation of seedlings. Thus volunteer seedlings under lower submergence level would activate the anti-oxidation mechanism in order to prevent the oxidant damage caused by flooding stress. However, under higher flooding level $(4.5-6.5 \mathrm{~cm})$, the submergence stress during germination and seedling development already caused irreversible damage and even destroyed the anti-oxidative system, so that the POD, SOD and CAT activities decreased while the MDA content increased greatly. Moreover, Changnongjing 1 and F2 generation of Yliangyoul173 were sensitive to flooding stress so that the anti-oxidative enzymatic activities declined in $\mathrm{F} 1$ and $\mathrm{F} 2$.

\section{Conclusion}

In conclusion, long-term ( 2 weeks) flooding treatment significantly limited or even prevented the germination and growth of volunteer rice, while treatment F4 $(6.0-6.5 \mathrm{~cm})$ 
was the most effective because of the lowest seedling rate. In order to prevent the harvest loss in late season rice caused by volunteer rice and further investigation should be at the field trials, the possible effects of flooding on the late-season rice production should be studied before the real application.

Acknowledgements. This study was funded by National Natural Science Foundation of China (31271646), The World Bank Loan Agricultural Pollution Control Project in Guangdong (07241510A08N3684) and (2017LM1098). The authors declare no conflicts of interest.

\section{REFERENCES}

[1] Aebi, H. (1984): Catalase in vitro. - Methods Enzymol 105: 121-126.

[2] Bird, J. A., Eagle, A. J., Horwath, W. R., Hair, M. W., Zibert, E. E., Van, K. C. (2002): Long-term studies find benefits, challenges in alternative rice straw management. California Agriculture 56: 69-75.

[3] Cao, Q., Bao-Rong, L. U., Xia, H., Rong, J., Sala, F., Spada, A., Grassi, F. (2006): Genetic diversity and origin of weedy rice (Oryza sativa f. spontanea) populations found in north-eastern China revealed by simple sequence repeat (SSR) markers. - Annals of Botany 98: 1241-1252.

[4] Dash, S., Mohanty, N. (2002): Response of seedlings to heat-stress in cultivars of wheat: Growth temperature-dependent differential modulation of photosystem 1 and 2 activity, and foliar antioxidant defense capacity. - Journal of Plant Physiology 159: 49-59.

[5] Ella, E. S., Kawano, N., Yamauchi, Y., Tanaka, K., Ismail, A. M. (2003): Blocking ethylene perception enhances flooding tolerance in rice seedlings. - Functional Plant Biology 30: 813-819.

[6] Ellis, R. (1981): The quantification of ageing and survival in orthodox seeds. - Seed Science \& Technology 9: 373-409.

[7] Ellstrand, N. C., Prentice, H. C., Hancock, J. F. (1999): Gene flow and introgression from domesticated plants into their wild relatives. - Horizontal Gene Transfer 30: 539-563.

[8] Elshintinawy, F. (2000): Structural and functional damage caused by boron deficiency in sunflower leaves. - Photosynthetica 36: 565-573.

[9] Farooq, M., Basra, S. M. A., Hafeez, K., Warriach, E. A. (2013): Influence of high- and low-temperature treatments on seed germination and seedling vigor of coarse and fine rice. - Custom Integrated Circuits Conference, 1992, Proceedings of the IEEE, 12.2.112.2.4.

[10] Fogliatto, S., Vidotto, F., Ferrero, A. (2010): Effects of winter flooding on weedy rice (Oryza sativa L.). - Crop Protection 29: 1232-1240.

[11] Gealy, D. R., Gressel, J. (2005): Gene Movement Between Rice (Oryza sativa) and Weedy Rice (Oryza sativa). A U.S. Temperate Rice Perspective. - In: Gressel, J. (ed.) Crop Ferality and Volunteerism. CRC Press, Boca Raton, FL, pp. 323-354.

[12] Gealy, D. R., Mitten, D. H., Neil, R. J. (2003): Gene flow between red rice (Oryza sativa) and herbicide-resistant rice (O. sativa): implications for weed management. - Weed Technology 17: 627-645.

[13] Gressel, J., Valverde, B. E. (2010): A strategy to provide long-term control of weedy rice while mitigating herbicide resistance transgene flow, and its potential use for other crops with related weeds. - Pest Management Science 65: 723-731.

[14] Huang, M., Ibrahim, M. D., Xia, B., Zou, Y. (2011): Significance, progress and prospects for research in simplified cultivation technologies for rice in China. - Journal of Agricultural Science 149: 487-496. 
[15] Huang, M., Zhou, X., Chen, J., Cao, F., Zou, Y., Jiang, L. (2016): Factors contributing to the superior post-heading nutrient uptake by no-tillage rice. - Field Crops Research 185: 40-44.

[16] Ismail, A. M., Ella, E. S., Vergara, G. V., Mackill, D. J. (2009): Mechanisms associated with tolerance to flooding during germination and early seedling growth in rice (Oryza sativa). - Annals of Botany 103: 197-209.

[17] Jackson, M. B., Ram, P. C. (2003): Physiological and molecular basis of susceptibility and tolerance of rice plants to complete submergence. - Ann Bot 91: 227-241.

[18] Jiang, M., Zhang, J. (2002): Water stress-induced abscisic acid accumulation triggers the increased generation of reactive oxygen species and up-regulates the activities of antioxidant enzymes in maize leaves. - Journal of Experimental Botany 53: 2401-2410.

[19] Kong, L., Ashraf, U., Cheng, S., Rao, G., Mo, Z., Tian, H., Pan, S., Tang, X. (2017): Short-term water management at early filling stage improves early-season rice performance under high temperature stress in South China. - European Journal of Agronomy 90: 117-126.

[20] Pan, S. (2013): Roles of plant growth regulators on yield, grain qualities and antioxidant enzyme activities in super hybrid rice (Oryza sativa L.). - Rice 6: 1-10.

[21] Peigné, J., Vian, J. F., Payet, V., Saby, N. (2018): Soil fertility after 10 years of conservation tillage in organic farming. - Soil \& Tillage Research 175: 194-204.

[22] Prakash, M., Sunilkumar, B., Narayanan, G. S., Gokulakrishnan, J., Anandan, R. (2016): Seed germination and seedling growth of rice varieties as affected by flooding stress. Indian Journal of Agricultural Research 50. DOI: 10.18805/ijare.v50i3.10748.

[23] Rajjou, L., M. Duval, Gallardo, K., Catusse, J., Bally, J., Job, C., Job, D. (2012): Seed germination and vigor. - Annual Review of Plant Biology 63: 507-533.

[24] Rakwal, R., Agrawal, G. K., Kubo, A., Yonekura, M., Tamogami, S., Saji, H., Iwahashi, H. (2003): Defense/stress responses elicited in rice seedlings exposed to the gaseous air pollutant sulfur dioxide. - Environmental \& Experimental Botany 49: 223-235.

[25] Ruan, S., Xue, Q., Tylkowska, K. (2002): The influence of priming on germination of rice (Oryza sativa L.) seeds and seedling emergence and performance in flooded soil. Seed Science \& Technology 30: 61-67.

[26] Sairam, R. K., Srivastava, G. C., Saxena, D. C. (2000): Increased antioxidant activity under elevated temperatures: a mechanism of heat stress tolerance in wheat genotypes. Biologia Plantarum 43: 245-251.

[27] Shivrain, V. K., Burgos, N. R., Anders, M. M., Rajguru, S. N., Moore, J., Sales, M. A. (2007): Gene flow between Clearfield rice and red rice. - Crop Protection 26: 349-356.

[28] Singh, V., Burgos, N., Singh, S., Abugho, S., Earnest, L., Gbur, E., Scott, R. (2016a): Herbicide and winter flood treatments for controlling volunteer rice off-season. - Crop Protection 79: 87-96.

[29] Singh, V., Burgos, N. R., Singh, S., Gealy, D. R., Gbur, E. E., Caicedo, A. L. (2016b): Impact of volunteer rice infestation on yield and grain quality of rice. - Pest Management Science 73: 604.

[30] Street, J. E., Teresiak, H., Boykin, D. L., Allen, R. L. (1995): Interaction between timings and doses of quinclorac in rice. - Weed Research 35: 75-79.

[31] Sudianto, E., Song, B. K., Ting-Xiang, N., Saldain, N. E., Scott, R. C., Burgos, N. R. (2013): Clearfield ${ }^{\circledR}$ rice: its development, success, and key challenges on a global perspective. - Crop Protection 49: 40-51.

[32] Triplett, G. B., Dick, W. A. (2008): No-tillage crop production: a revolution in agriculture! - Agronomy Journal 100: 153-S165.

[33] Warwick, S. I., Stewart, C. N. J., Gressel, J. (2005): Crops come from wild plants - how domestication, transgenes, and linkage together shape ferality. - Crop Ferality \& Volunteerism 36: 30.

[34] Wiesner, L. (1990): Rules for Testing Seeds. Rev. - Information Systems Division, National Agricultural Library, Beltsville, MD, Washington, DC. 
[35] Xia, X. J., Wang, Y. J., Zhou, Y. H., Yuan, T., Mao, W. H., Kai, S., Asami, T., Chen, Z. X., Yu, J. Q. (2009): Reactive oxygen species are involved in brassinosteroid-induced stress tolerance in cucumber. - International Journal of Rock Mechanics \& Mining Sciences \& Geomechanics Abstracts 150: 801-814.

[36] Zhang, W. F., Zhang, F., Raziuddin, R., Gong, H. J., Yang, Z. M., Lu, L., Ye, Q. F., Zhou, W. J. (2008): Effects of 5-aminolevulinic acid on oilseed rape seedling growth under herbicide toxicity stress. - Journal of Plant Growth Regulation 27: 159-169.

\section{APPENDIX}

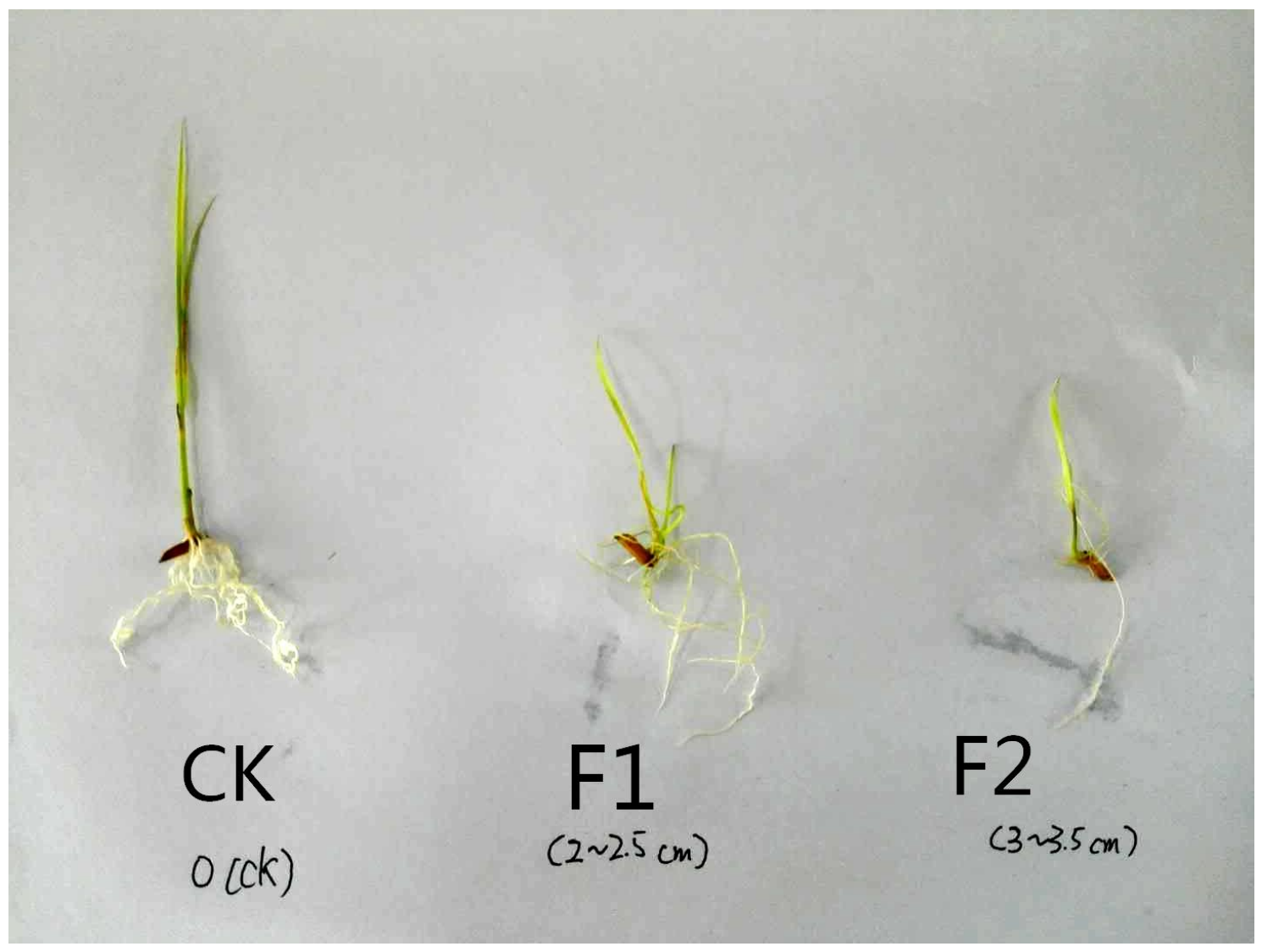

